\title{
Kajian yuridis komparatif tentang sistem pemilihan presiden langsung dan pelaksanaannya di Indonesia
}

\section{Triwahyuningsih ${ }^{\mathrm{a}, 1^{*}}$}

a Program Studi PPKn, Universitas Ahmad Dahlan, Yogyakarta

${ }^{1}$ triwahyuningsih@ppkn.uad.ac.id

${ }^{*}$ Korespondensi penulis

\begin{abstract}
ABSTRAK
UUD 1945 pasca amandemen tidak mengatur tentang pelaksanaan pemilihan presiden langsung oleh rakyat. Pasal 6A UUD 1945 dalam hal ini menentukan (1) Presiden dan Wakil Presiden dipilih dalam satu pasangan secara langsung oleh rakyat dan (5) Tata cara pelaksanaan pemilihan umum Presiden dan Wakil Presiden lebih lanjut diatur dengan Undangundang. Akhirnya pelaksanaan pemilihan presiden langsung diserahkan kepada pembentuk undang-undang. Oleh karena itu telah berganti tiga kali pengaturan selama pemilihan presiden langsung, yaitu Undang-Undang No. 23 Tahun 2003 tentang Pemilihan Presiden dan Wakil Presiden untuk pemilihan Presiden dan Wakil Presiden 2004, UndangUndang No. 42 Tahun 2008 tentang Pemilihan Umum Presiden dan Wakil Presiden untuk Pemilihan Presiden dan Wakil Presiden 2009 dan 2014 dan UU No. 7 Tahun 2017 untuk pemilu serentak 2019. Tujuan penelitian ini adalah untuk menganalisis perbandingan pengaturan tentang sistem pemilihan presiden langsung dalam konstitusi dan pelaksanaannya di Indonesia dan perbedaan serta implikasinya dalam sistem ketatanegaraan negara Indonesia.
\end{abstract}

Kata kunci: yuridis, komparatif, pemilihan Presiden langsung

\section{ABSTRACT}

Constitution 1945 after amendment did not regulate about the implementation of the direct presidential election. Article 6 A Constitution 19945 determined: (1) The President and Vice-President shall be elected as a pair directly by the people. (5) The procedure for the holding of the election of the President and Vice President shall further be regulated by law. As consequences, the implementation of a direct presidential election given to legislator. Therefore, it has been changed 3 times during the direct presidential election, which is: Law No. 23 Year 2003 about President and Vice President Election this used as regulation for 2004 President and Vice President Election, Law No. 42 the year 2008 about President and Vice President Election this used as regulation for 2009 and 2014 President and Vice President Election, and Law No. 7 Year 2017 for the 2019 concurrent election. This research aims to analyze and compare regulation about direct presidential election system in the constitution and its implementation and also its different implication in the constitutional system of Indonesia.

Keywords: a juridical, comparative, direct presidential system

Copyright (C2018Universitas Ahmad Dahlan, All Right Reserved

\section{PENDAHULUAN}

Ajaran kedaulatan rakyat meyakini bahwa yang sesungguhnya berdaulat dalam setiap negara adalah rakyat. Kehendak rakyat merupakan satusatunya sumber kekuasaan bagi setiap pemerintah (Asshiddiqie, 1994). Bagaimana kekuasaan dan otoritas itu berasal, berikut bagaimana kekuasaan itu teralokasi dan terdistribusi, merupakan masalah sentral diskusi sebelum dan sesudah terjatuhnya pemerintahan Orde Baru (Marijan, 2010). Satu pandangan yang memiliki benang merah antara kelompok pro demokrasi yang satu dengan yang lain adalah bahwa untuk membangun negara Indonesia modern dan demokratis ke depan diperlukan kekuasaan yang bersumber dari rakyat dan digunakan serta berorientasi untuk rakyat, adanya pembatasan bagi para pemegang kekuasaan, serta adanya pemisahan dan pembagian kekuasaan.(Marijan, 2010).

Pemilihan presiden langsung secara otomatis mengakhiri kekuasaan MPR sekaligus memberikan legitimasi yang kuat kepada presiden di satu sisi dan rakyat juga memiliki kesempatan yang luas untuk memilih dan menilai sendiri calon pemimpinnya. Perubahan ini memiliki aspek positif untuk mendorong perubahan format politik ketatanegaraan dan pengembalian kedaulatan kepada rakyat (Amalia, 2016). Di samping itu pemilihan presiden langsung oleh rakyat memberikan basis legitimasi politik yang kuat bagi presiden. Hasil pemilihan presiden langsung diharapkan terbentuk kelembagaan presidensial kuat karena mengakar pada kehendak mayoritas rakyat. Di satu pihak ada keinginan untuk memperkuat pelembagaan sistem demokrasi 
presidensial, namun di pihak lain tidak ada upaya untuk mengimplementasikan skema presidensial secara konsisten (Haris, 2016).

Pengalaman pemilu nasional pasca Soeharto dalam tiga periode kepemimpinan, memperlihatkan hasil yang tidak membawa pada penguatan sistem presidensial. Desain pelaksanaan pemilu tidak berjalan seiring dengan rancang bangun sistem pemerintahan sebagaimana yang dikonstruksikan dalam amandemen konstitusi UUD 1945 (Hidayanto, 2017). Model pemilihan umum semenjak amandemen UUD 1945, di mana pemilihan umum Presiden dan Wakil Presiden terpisah dengan pemilu DPR, DPD dan DPRD, dapat dikatakan sebagai eksperimen pertama dalam ketatapemiluan Indonesia (Hidayanto, 2017). Putusan Mahkamah Konstitusi No.14/PUUXI/2013 dengan mengabulkan uji materi Undangundang No. 42 Tahun 2008 tentang Pemilihan Presiden dan Wakil Presiden memutuskan pemilu legislative dan pemilu presiden harus dilaksanakan secara bersamaan (serentak).

Undang-Undang Dasar 1945 hasil amandemen menunjukkan bahwa kedaulatan rakyat dibagikan secara horizontal dengan cara memisahkannya (separation of power) menjadi kekuasaan yang dinisbatkan sebagai fungsi lembaga-lembaga negara yang sederajat dan saling mengendalikan satu sama lain berdasarkan prinsip checks and balances. Pembaharuan mekanisme ketatanegaraan tersebut juga diwujudkan dalam membangun sistem pemerintahan Indonesia.

Implementasi konstitusi tidak selalu seperti ketentuan tekstual yang ada. Praktik berkonstitusi ditentukan oleh beragam faktor. Kekuatankekuatan politik yang dominan akan mewarnai pelaksanaan konstitusi, seperti dalam legislasi di parlemen dan implementasinya oleh birokrasi. Konstitusi tidak bekerja atau diterapkan di ruang hampa, sebagaimana ia memang tidak dirumuskan atau datang secara tiba-tiba (Falaakh, 2006) Undang-Undang Dasar tidak dapat dipahami hanya melalui teksnya saja. Untuk sungguhsungguh mengerti, harus memahami konteks filosofis, sosio-historis, sosio-politis, sosio-yuridis dan bahkan sosio-ekonomis yang mempengaruhi perumusannya (Asshiddiqie, 2009). Dalam perjalanan sejarah kondisi-kondisi kehidupan yang membentuk dan mempengaruhi kerangka pemikiran (frame of reference) dan pengalaman (field of experience) dengan muatan kepentingan yang berbeda, sehingga pemahaman terhadap suatu ketentuan Undang-Undang Dasar berkembang dalam praktik di kemudian hari (Asshiddiqie, 2009).
Perbandingan pengaturan tentang sistem pemilihan presiden langsung dalam konstitusi dan pelaksanaannya di Indonesia, perbedaan serta implikasinya dalam sistem ketatanegaraan negara Indonesia menjadi urgen untuk mengetahui latar belakang, perbedaan serta implikasi dari pengaturan pelaksanaan pemilihan presiden langsung tahun 2004, 2009, 2014 dan 2019.

Artikel ini mengkaji bagaimana perbandingan pengaturan tentang sistem pemilihan presiden langsung dalam konstitusi dan pelaksanaannya di Indonesia, perbedaan dan implikasinya dalam sistem ketatanegaraan negara Indonesia.

\section{METODE PENELITIAN}

Jenis penelitian ini adalah penelitian hukum normatif, yakni penelitian hukum yang dilakukan dengan cara meneliti bahan pustaka atau data sekunder atau library research. Menggunakan pendekatan yuridis, historis, komparatif, menggunakan beberapa penafsiran hukum, yaitu penafsiran gramatikal atau interpretasi bahasa; penafsiran sistematis; penafsiran sejarah undangundang; Penafsiran sejarah hukum. Menggunakan bahan hukum sekunder dan tersier. Analisis data menggunakan yuridis interpretasi dan dianalisis secara kualitatif yaitu dengan menjabarkan, menginterpretasikan dan menyusun secara sistematis-logis sesuai tujuan penelitian. Kemudian hasil penelitian dilakukan penarikan kesimpulan terhadap masalah tersebut dengan metode deduktif dan disajikan secara deskriptif analitis.

\section{HASIL DAN PEMBAHASAN}

Demokrasi secara sederhana merupakan sebuah metode politik, sebuah mekanisme untuk memilih pemimpin politik. Warga negara diberikan kesempatan untuk memilih salah satu diantara pemimpin-pemimpin politik yang bersaing meraih suara. Metode demokratis adalah penataan kelembagaan untuk sampai pada keputusan politik dimana individu meraih kekuasaan untuk mengambil keputusan melalui perjuangan kompetitif untuk meraih suara (Sørensen, 2008).

Sistem demokrasi yang ada di Indonesia salah satunya adalah yang berkaitan dengan partisipasi rakyat secara langsung dalam mekanisme pemerintahan. Dalam prosesnya, sistem kedaulatan rakyat ini diimplementasikan melalui sistem yang langsung (direct democracy) dan sistem perwakilan (indirect democracy/representative democracy) (Rositawati, 2009). Mekanisme ini terwujud dalam suatu sistem pemilu langsung yang disebutkan dalam ketentuan Pasal 22E (2) UUD 1945 yang menegaskan sebagai berikut: "Pemilihan 
umum diselenggarakan untuk memilih anggota Dewan Perwakilan Rakyat, Dewan Perwakilan Daerah, Presiden dan Wakil Presiden dan Dewan Perwakilan Rakyat Daerah." Sedangkan representative democracy diimplementasikan melalui DPR dan DPD. Representative democracy dimaknakan sebagai mekanisme perwakilan representation (Rositawati, 2009).

Proses pemilihan presiden dan wakil presiden di Indonesia dipandang sebagai suatu proses yang berbeda dan dibedakan secara tegas dari proses pemilihan umum untuk mengisi keanggotaan lembaga perwakilan rakyat (DPR). Secara konsep pemilihan umum (general election) dan pemilihan presiden (presidential election) merupakan hal yang berbeda. Pemilihan presiden merupakan perwujudan dianutnya kedaulatan rakyat (demokrasi) untuk memilih pemimpin secara langsung (direct democracy), sementara itu, untuk pemilihan umum legislatif adalah sebuah mekanisme untuk memilih wakil-wakil rakyat sebagai perwujudan kedaulatan rakyat untuk mengendalikan dan mengawasi jalannya pemerintahan melalui sistem perwakilan (indirect democracy) (Rositawati, 2009).

Amandemen Undang-Undang Dasar 1945 menunjukkan dua hal yang berlawanan di satu sisi memperkuat posisi Presiden karena dipilih langsung oleh rakyat melalui pemilu sehingga mendapat legitimasi langsung dari rakyat dan kedudukannya menjadi lebih kuat di hadapan lembaga negara lainnya. Di sisi lain mereduksi kewenangan Presiden sebagaimana diatur dalam UUD 1945 sebelum perubahan. Berdasarkan amandemen UUD 1945 ditegaskan bahwa presiden dipilih secara langsung oleh rakyat. Pasal 6A UUD 1945 dalam hal ini menentukan:

(1) Presiden dan Wakil Presiden dipilih dalam satu pasangan secara langsung oleh rakyat.

(2) Pasangan calon Presiden dan Wakil Presiden diusulkan oleh partai politik atau gabungan partai politik peserta pemilihan umum sebelum pelaksanaan pemilihan umum.

(3) Pasangan calon Presiden dan Wakil Presiden yang mendapat suara lebih dari lima puluh persen dari jumlah suara pemilih dengan sedikitnya dua puluh persen suara di setiap propinsi yang tersebar di lebih dari setengah jumlah propinsi di Indonesia, dilantik menjadi Presiden dan Wakil Presiden.

(4) Dalam hal tidak ada pasangan calon Presiden dan Wakil Presiden terpilih, dua pasangan calon yang memperoleh suara terbanyak pertama dan kedua dalam pemilu dipilih oleh rakyat secara langsung dan pasangan yang memperoleh suara terbanyak dilantik sebagai pasangan Presiden dan Wakil Presiden.

(5) Tata cara pelaksanaan pemilihan umum Presiden dan Wakil Presiden lebih lanjut diatur dengan Undang-undang.

Peraturan pelaksanaan dari ketentuan mengenai pemilihan umum Presiden dan Wakil Presiden sebagaimana ditegaskan pada Pasal 6A UUD 1945 adalah Undang-Undang No. 23 Tahun 2003 tentang Pemilihan Presiden dan Wakil Presiden untuk pemilihan Presiden dan Wakil Presiden 2004, Undang-Undang No. 42 Tahun 2008 tentang Pemilihan Umum Presiden dan Wakil Presiden untuk Pemilihan Presiden dan Wakil Presiden 2009 dan 2014, Undang-undang No.7 Tahun 2017 untuk pemilu serentak 2019.

Salah satu cara yang paling mudah dan praktis membatasi kekuasaan penguasa adalah dengan pemilihan para penguasa oleh rakyat yang akan diperintah, termasuk pemilihan presiden. Sedangkan cara yang lain menurut adalah dengan sistem pembagian kekuasaan dan kontrol yurisdiksional (Soehino, 1998). Dalam suatu negara demokrasi, pada umumnya pengisian jabatan presiden dilakukan melalui pemilihan oleh rakyat (korps pemilih), yang diatur dengan perundang-undangan dan alon presiden pada negara demokrasi pada umumnya ditentukan melalui seleksi yang dilakukan oleh partai politik (Rauta, 2014)

\section{Perbandingan Pengaturan pemilihan Presiden langsung}

Walaupun rujukan pengaturan tentang pemilihan presiden langsung sama, yaitu Pasal 6 A dalam UUD 1945 namun dalam pelaksanaannya mengalami perbedaan antara pilpres 2004, 2009, 2014 dan 2019. Hal ini disebabkan Pasal 6A ayat ayat 5 bahwa "Tata cara pelaksanaan pemilihan umum Presiden dan Wakil Presiden lebih lanjut diatur dengan Undang-undang. Itu artinya bahwa pelaksanaan pemilihan presiden diserahkan sepenuhnya kepada pembentuk undang-undang. Kemudian terbentuklah UU No 23 Tahun 2003 untuk pilpres 2004, UU No. 42 Tahun 2008 untuk pilpres 2009 dan 2014, dan UU No. 7 Tahun 2017 untuk pemilu serentak 2019, termasuk pemilihan presiden, sebagaimana tergambar dalam table di bawah ini:

Tabel 1 Ketentuan Undang-Undang Pemilihan Presiden Undang-Undang yang Mengatur Pemilihan Presiden UU No. 23 Tahun 2003 tentang UU No. 42 Tahun 2008 tentang UU No. 7 Tahun 2017 tentang Pemilu Presiden dan Wakil Presiden Pemilu Presiden dan Wakil Presiden Pemilu untuk Pemilu serentak 2004 untuk Pilpres 2009 dan $2014 \quad 2019$ 
Undang-Undang yang Mengatur Pemilihan Presiden

1 - Pasal 3 Pasal 3

(5) Pemilu Presiden dan Wakil

(3) Pemilu Presiden dan Wakil

Presiden merupakan satu rangkaian dengan Pemilihan Umum anggota DPR, DPD dan DPRD

Presiden dilaksanakan setelah Pelaksanaan pemilihan umum anggota DPR, DPD dan DPRD
2 Pasal 4

Pemungutan suara untuk pelaksanaan Pemilu Presiden dan Wakil Presiden sebagaimana dimaksud dalam Pasal 3 ayat (1) dilaksanakan selambat-lambatnya 3(tiga) bulan setelah pengumuman hasil Pemilu bagi anggota DPR, DPD, DPRD Provinsi dan DPRD Kabupaten/Kota

3 Pasal 5

(1) Peserta Pemilu Presiden dan Wakil Presiden adalah Pasangan Calon yang diusulkan secara berpasangan oleh partai politik atau gabungan partai politik.

(2) Pengumuman calon Presiden dan/atau calon Wakil Presiden atau Pasangan calon oleh partai politik atau gabungan partai politik dapat dilaksanakan bersamaan dengan penyampaian daftar calon anggota DPR kepada Komisi Pemilihan Umum (KPU).

(3) Pendaftaran pasangan calon oleh partai politik atau gabungan partai politik dilaksanakan setelah memenuhi persyaratan perolehan kursi DPR atau perolehan suara sah yang ditentukan oleh undangundang ini kepada KPU.

(4) Pasangan Calon sebagaimana dimaksud pada ayat (1) hanya dapat diusulkan oleh partai politik atau gabungan partai politik yang memperoleh sekurang-kurangnya $15 \%$ (lima belas persen) dari jumlah kursi DPR atau 20\% (dua puluh persen) dari perolehan suara sah secara nasional dalam pemilu anggota DPR
Pasal 8

Calon Presiden dan Calon Wakil Presiden diusulkan dalam 1(satu) pasangan oleh Partai Politik atau Gabungan Partai Politik

Pasal 9

Pasangan Calon diusulkan oleh Partai Politik atau Gabungan Partai Politik peserta pemilu yang memenuhi persyaratan perolehan kursi paling sedikit 20\% (dua puluh persen) dari jumlah kursi DPR atau memperoleh $25 \%$ (dua puluh lima persen) dari suara sah nasional dalam Pemilu anggota DPR, sebelum pelaksanaan Pemilu Presiden dan Wakil Presiden.

\section{Pasal 12}

(1) Partai Politik atau Gabungan Partai Politik dapat mengumumkan bakal calon Presiden dan/atau bakal calon Wakil presiden dalam kampanye pemilihan umum anggota DPR, DPD dan DPRD.

\section{Pasal 1}

(1) Pemilu adalah sarana kedaulatan rakyat untuk memilih anggota Dewan Perwakilan Rakyat, anggota Dewan perwakilan Daerah, Presiden dan Wakil presiden, dan untuk memilih anggota Dewan Perwakilan Rakyat Daerah

Pasal 347

(1) Pemungutan suara Pemilu diselenggarakan secara serentak.

(2) Hari, tanggal, dan waktu pemungutan suara Pemilu. ditetapkan dengan keputusan KPU.

Pasal 221

Calon Presiden dan Wakil

Presiden diusulkan 1 (satu)

pasangan oleh Partai Politik dan Gabungan Partai Politik.

Pasal 222

Pasangan Calon diusulkan oleh Partai Politik atau Gabungan Partai Politik Peserta Pemilu yang memenuhi persyaratan perolehan kursi paling sedikit $20 \%$ (dua puluh persen) dari jumlah kursi DPR atau memperoleh $25 \%$ (dua puluh lima persen) dari suara sah secara nasional pada Pemilu anggota DPR sebelumnya.

\section{Pasal 225}

(1) Partai Politik atau Gabungan Partai Politik dapat mengumumkan bakal calon Presiden dan/atau bakal calon Wakil Presiden sebelum penetapan calon anggota. DPR, DPD, dan DPRD.

(2) Bakal calon Presiden dan/atau bakal calon Wakil Presiden yang diumumkan oleh Partai Politik atau Gabungan

Partai Politik sebagaimana dimaksud pada ayat (1) harus sudah mendapatkan persetujuan tertulis dari bakal calon yang bersangkutan

Pasal 226

(4) Masa pendaftaran bakal Pasangan Calon Presiden dan Wakil Presiden paling lama 8 
Undang-Undang yang Mengatur Pemilihan Presiden

(delapan) bulan sebelum hari pemungutan suara.

Sumber: data hasil penelitian, 2018

Pemilihan Presiden secara langsung telah terselenggara di tahun 2004, 2009 dan 2014 merupakan langkah penting bagi proses demokrasi di Indonesia. Pemilihan Presiden (pilpres) langsung tidak hanya dinilai sebagai sebuah prosedur pemilu, namun membuka peluang bagi seluruh warga negara untuk terlibat langsung dalam memilih pemimpin.

\section{Pemilihan Presiden 2004}

Berdasarkan ambang batas pencalonan presiden, maka hanya partai politik yang memiliki $3 \%$ dari jumlah kursi di DPR atau 5\% dari suara sah secara nasional hasil pemilu DPR yang dapat mencalonkan presiden dan wakil presiden. Sesuai dengan ketentuan tersebut, partai politik yang dapat mengikuti pilpres adalah Partai Persatuan Pembangunan, Partai Demokrat, Partai amanat Nasional, Partai Kebangkitan Bangsa, Partai Keadilan Sejahtera, Partai Demokrasi Indonesia Perjuangan, Partai Golongan Karya.

\section{Tabel 2 Parpol yang Memenuhi} Ambang Batas Pilpres 2004

\begin{tabular}{llcc}
\hline No & \multicolumn{1}{c}{ Nama Partai } & \% Jumlah Kursi & \% Jumlah Suara \\
\hline 1 & Partai Persatuan Pembangunan & $\mathbf{1 0 , 5 \%}$ & $\mathbf{8 , 1 \%}$ \\
2 & Partai Demokrat & $\mathbf{1 0 , 1 \%}$ & $\mathbf{7 , 4 \%}$ \\
3 & Partai Amanat Nasional & $\mathbf{9 , 6 \%}$ & $\mathbf{6 , 4 \%}$ \\
4 & Partai Kebangkitan Bangsa & $\mathbf{9 , 4 \%}$ & $\mathbf{1 0 , 5 \%}$ \\
5 & Partai Keadilan Sejahtera & $\mathbf{8 , 1 \%}$ & $\mathbf{7 , 3 \%}$ \\
6 & Partai Demokrasi Indonesia & $\mathbf{1 9 , 8 \%}$ & $\mathbf{1 8 , 5 \%}$ \\
& Perjuangan & & $\mathbf{2 1 , 5 \%}$ \\
7 & Partai Golongan Karya & $\mathbf{2 3 \%}$ &
\end{tabular}

Sumber: Komisi Pemilihan Umum, 2004.

Berdasarkan hasil Pemilu legislatif tahun 2004, hanya 7 dari 24 partai peserta pemilu yang dapat mencalonkan presiden dalam pilpres. Dengan demikian dalam konteks ketatanegaraan Indonesia, pentingnya partai politik sebagai salah satu sarana bagi warga negara untuk menentukan wakil rakyat di lembaga perwakilan dan pemimpin pemerintahan di lembaga eksekutif. Jadi partai politik merupakan "kendaraan" seseorang untuk dapat mencalonkan diri dalam pemilihan presiden. Dari tujuh partai politik yang lolos ambang batas, terdapat enam partai yang akhirnya mendaftarkan pasangan capres dan cawapresnya, yaitu:

1. Wiranto dan Salahudin Wahid, dicalonkan oleh Partai Golkar,

2. Megawati Soekarnoputri dan ahmad Hasyim Muzadi, dicalonkan oleh PDIP

3. Amin Rais dan Siswono Yudohusodo, dicalonkan oleh Partai amanat Nasional;

4. Susilo Bambang Yudhoyono (SBY) dan Muhammad Yusuf Kalla, dicalonkan oleh Partai Demokrat;

5. Hamzah Haz dan Agum Gumelar, dicalonkan oleh Partai Persatuan Pembangunan;

6. Abdurrahman Wahid dan Marwah Daud Ibrahim, dicalonkan oleh Partai Kebangkitan Bangsa.
Tidak seluruh bakal calon presiden dan wakil presiden tersebut lolos mengikuti pilpres. Adalah Aburrahman Wahid yang diusung oleh PKB setelah melalui serangkaian pemeriksaan kesehatan oleh Ikatan dokter Indonesia (IDI) dinyatakan tidak memenuhi syarat kemampuan jasmani dan rohani (Komisi Pemilihan Umum, 2004). Upaya hukum telah dilakukan untuk mmempertahankan pencalonan Abdurrahman wahid, namun gagal. Partai Kebangkitan Bangsa (PKB) menyatakan diri mendukung capres yang diusulkan Golkar karena dianggap dapat menjadi representasi kelompok Nahdatul Ulama (NU) (Budiatri, 2016).

Melalui Surat keputusan KPU (SK) KPU No. 36/2004, KPU mengumumkan lima pasangan capres dan cawapres berdasarkan nomor urut (1) Wiranto-Salahudin, (2) Megawati-Hasyim, (3) Amin Rais- Siswono, (4) SBY- Kalla, (5) Hamzah Haz-Agum. Kelima nama tersebut merupakan pasangan calon yang pertama kali mengikuti pemilihan presiden langsung oleh rakyat (Budiatri, 2016).

Apabila dilihat dari ketentuan ambang batas untuk bisa mengajukan calon presiden dan wakil presiden pada pilpres 2004 diatur ketentuan sebagaimana pada Pasal 5 ayat (4) pasangan calon sebagaimana dimaksud pada ayat (1) hanya dapat 
diusulkan oleh partai politik atau gabungan partai politik yang memperoleh sekurang-kurangnya $15 \%$ (lima belas persen) dari jumlah kursi DPR atau 20\% (dua puluh persen) dari perolehan suara sah secara nasional dalam pemilu anggota DPR. Berarti dari hasil pemilu 2004 hanya Golkar yang memperoleh
$21,62 \%$ dan PDIP yang memperoleh $18,31 \%$ yang dapat mencalonkan Presiden dan wakil presiden tanpa harus koalisi dengan partai lain. Sementara partai yang lain harus berkoalisi untuk dapat mencalonkan calon Presiden dan wakil presiden. Hasil pilpres putaran pertama sebagai berikut:

Tabel 3 Hasil Pilpres Putaran Pertama

\begin{tabular}{|c|c|c|c|c|}
\hline No & $\begin{array}{c}\text { Nama Pasangan Capres dan } \\
\text { Cawapres }\end{array}$ & Partai Pendukung & Perolehan suara & $\begin{array}{c}\text { Persentase } \\
(\%)\end{array}$ \\
\hline 1 & $\begin{array}{l}\text { H. wiranto, SH } \\
\text { Ir. H. Salahudin Wahid }\end{array}$ & Golkar & 23.827 .512 & 22,19 \\
\hline 2 & $\begin{array}{l}\text { Megawati Soekarnoputri } \\
\text { K.H ahmad Hasyim Muzadi }\end{array}$ & PDIP & 28.186 .780 & 26,24 \\
\hline 3 & $\begin{array}{l}\text { Amin Rais } \\
\text { Siswono Yudo Husodo }\end{array}$ & PAN & 16.042 .105 & 14,94 \\
\hline 4 & $\begin{array}{l}\text { Susilo Bambang Yudhoyono } \\
\text { M Yusuf Kalla }\end{array}$ & $\begin{array}{l}\text { Demokrat, PBB, } \\
\text { PKPI }\end{array}$ & 36.070 .622 & 33,58 \\
\hline 5 & $\begin{array}{l}\text { Hamzah Haz } \\
\text { Agum Gumelar }\end{array}$ & PPP & 3.276 .001 & 13,05 \\
\hline
\end{tabular}
Sumber : http:/www.kpu.go.id diakses 31 Juli 2018

Pasal 6A UUD 1945 (3) disebutkan bahwa Pasangan calon Presiden dan Wakil Presiden yang mendapat suara lebih dari lima puluh persen dari jumlah suara pemilih dengan sedikitnya dua puluh persen suara di setiap propinsi yang tersebar di lebih dari setengah jumlah propinsi di Indonesia, dilantik menjadi Presiden dan Wakil Presiden. Berdasarkan tabel di atas, pelaksanaan pilpres putaran pertama tidak ada yang mendapatkan suara 50\% sehingga harus dilaksanakan puritan kedua dari dua pasangan calon yang memperoleh suara terbanyak pertama dan kedua. Dalam putaran kedua pasangan SBY-JK mengalahkan pasangan Megawati-Hasyim dengan data lengkap sebagai berikut:

Tabel 4 Perolehan Suara Pilpres 2004 Putaran Kedua

\begin{tabular}{l|l|c|c}
\hline No & Pasangan Calon & Suara & (\%) \\
\hline 1 & $\begin{array}{l}\text { Susilo Bambang Yudhoyono-Yusuf } \\
\text { Kalla }\end{array}$ & 69.266 .350 & 60,62 \\
\hline 2 & $\begin{array}{l}\text { Megawati Soekarnoputri-Hasyim } \\
\text { Muzadi }\end{array}$ & 44.990 .704 & 39,38 \\
\hline \multicolumn{2}{c}{ Sumber : http:/www. kpu.go.id diakses 31 Juli 2018 }
\end{tabular}

\section{Pemilihan Presiden 2009 dan 2014}

Dasar hukum pemilihan presiden 2009 dan 2014 sama yaitu Undang-Undang No. 42 Tahun 2008 tentang Pemilihan Umum Presiden dan wakil presiden Republik Indonesia. Persyaratan lebih ketat yaitu Pasangan Calon diusulkan oleh Partai Politik atau Gabungan Partai Politik peserta pemilu yang memenuhi persyaratan perolehan kursi paling sedikit $20 \%$ (dua puluh persen) dari jumlah kursi DPR atau memperoleh $25 \%$ (dua puluh lima persen) dari suara sah nasional dalam Pemilu anggota DPR, sebelum pelaksanaan Pemilu Presiden dan Wakil Presiden.

Adapun pelaksanaan pilpres tahun 2009 dapat ditentukan hanya dalam satu kali putaran, sebab pasangan Susilo Bambang Yudhoyono-Boediono mampu mengungguli pasangan Megawati Soekarno Putri-Prabowo Subianto dan pasangan Jusuf Kalla-Wiranto dengan meraih $60,8 \%$ suara pada putaran pertama, sebagaimana terlihat dalam tabel berikut :

Tabel 5 Perolehan Suara Pasangan Capres-Cawapres pada Pilpres 2009

\begin{tabular}{|c|c|c|c|}
\hline $\begin{array}{l}\text { Pasangan } \\
\text { Calon }\end{array}$ & Partai Pendukung & $\begin{array}{l}\text { Perolehan } \\
\text { Suara }\end{array}$ & $\%$ \\
\hline $\begin{array}{l}\text { Megawati- } \\
\text { Prabowo }\end{array}$ & $\begin{array}{l}\text { PDIP, Gerindra, PNI, Partai Buruh, Partai Merdeka, Partai Kedaulatan, } \\
\text { PSI, PPNUI }(21,43) \%\end{array}$ & 32.548 .105 & 26,79 \\
\hline $\begin{array}{l}\text { SBY- } \\
\text { Boediono }\end{array}$ & $\begin{array}{l}\text { Partai Demokrat, PKS, PAN, PPP, PKB, PBB, PDS, PKPB, PBR,PPRN, } \\
\text { PKPI, PDP, PPPI, Partai RepublikaN, Partai Patriat, PNBKI, PMB, PPI, } \\
\text { Partai Pelopor, PKDI, PIS, PIB, Partai PDI }(56,61 \%)\end{array}$ & 73.874 .562 & 60,80 \\
\hline JK-Wiranto & $\begin{array}{l}\text { Partai Golkar dan Partai Hanura } \\
(21,96) \%\end{array}$ & 15.081 .814 & 12,41 \\
\hline
\end{tabular}

Sumber, http: www.kpu.go.id. Diakses 31 Juli 2018 

Berbeda dengan pilpres 2004 dan 2009, dalam pilpres $2014 \mathrm{KPU}$ menetapkan pilpres hanya dilaksanakan dalam satu kali putaran, sebab berdasarkan putusan uji materi Mahkamah Konstitusi Pasal 159 Ayat (1) Undang-Undang No 42/2008 tentang Pemilu Presiden, pasangan calon presiden dan wakil presiden yang terpilih adalah pasangan calon yang memiliki suara terbanyak sehingga tidak perlu dilakukan pemilihan putaran kedua. Berdasarkan Keputusan Komisi Pemilihan Umum (KPU) Nomor : 536/Kpts/KPU/Tahun 2014 tentang Penetapan Pasangan Calon Presiden dan Wakil Presiden Terpilih dalam Pemilihan Umum Presiden dan Wakil Presiden Tahun 2014, yaitu Joko Widodo- Yusuf Kalla dengan 53,15\% suara sah nasional dengan tabel sebagai berikut:

Tabel 6 Perolehan Suara Pasangan Capres-Cawapres pada Pilpres 2014

\begin{tabular}{llllc}
\hline No & $\begin{array}{l}\text { Calon Presiden- } \\
\text { Wakil Presiden }\end{array}$ & \multicolumn{1}{c}{ Partai Pendukung } & $\begin{array}{c}\text { Hasil } \\
\text { Perolehan } \\
\text { Suara }\end{array}$ & $\%$ \\
\hline 1 & $\begin{array}{l}\text { Prabowo } \\
\text { Subiyanto-Hatta }\end{array}$ & $\begin{array}{l}\text { Partai Gerindra, Partai Amanat Nasional (PAN), Partai } \\
\text { Persatuan Pembangunan (PPP), Partai Keadilan Sejahtera } \\
\text { (PKS), Partai Golkar, dan Partai Bulan Bintang (PBB) }\end{array}$ & 62.576 .444 & $46,85 \%$ \\
2 & $\begin{array}{l}\text { Rajasa } \\
\text { Joko Widodo- } \\
\text { Jusuf Kalla }\end{array}$ & PDI Perjuangan, Nasdem, PKB, Hanura dan PKPI & 70.997 .833 & $53,15 \%$ \\
\hline
\end{tabular}

Diolah dari http://www.kpu.go.id

\section{KESIMPULAN}

UUD 1945 pasca amandemen tidak mengatur tentang pelaksanaan pemilihan presiden langsung oleh rakyat. Pasal 6A UUD 1945 dalam hal ini menentukan presiden dan wakil Presiden dipilih dalam satu pasangan secara langsung oleh rakyat dan tata cara pelaksanaan pemilihan umum Presiden dan Wakil Presiden lebih lanjut diatur dengan Undang-undang. Akhirnya pelaksanaan pemilihan presiden langsung diserahkan kepada pembentuk undang-undang. Oleh karena itu telah berganti 3 kali pengaturan selama pilpres langsung, yaitu Undang-Undang No. 23 Tahun 2003 tentang Pemilihan Presiden dan Wakil Presiden untuk pemilihan Presiden dan Wakil Presiden 2004, Undang-Undang No. 42 Tahun 2008 tentang Pemilihan Umum Presiden dan Wakil Presiden untuk Pemilihan Presiden dan Wakil Presiden 2009 dan 2014 dan UU No. 7 Tahun 2017 untuk pemilu serentak 2019.

Pasangan Calon Presiden dan Wakil Presiden pada tahun 2004 dapat diusulkan oleh partai politik atau gabungan partai politik yang memperoleh sekurang-kurangnya $15 \%$ (lima belas persen) dari jumlah kursi DPR atau 20\% (dua puluh persen) dari perolehan suara sah secara nasional dalam pemilu anggota DPR. Sedangkan pilpres 2009 dan 2014 persyaratannya menjadi parpol atau gabungan parpol yang perolehan kursi paling sedikit $20 \%$ (dua puluh persen) dari jumlah kursi DPR atau memperoleh $25 \%$ (dua puluh lima persen) dari suara sah nasional dalam Pemilu anggota DPR, sebelum pelaksanaan Pemilu Presiden dan Wakil Presiden. Sedangkan untuk pilpres 2019 adalah Partai Politik atau Gabungan Partai Politik Peserta Pemilu yang memenuhi persyaratan perolehan kursi paling sedikit $20 \%$ (dua puluh persen) dari jumlah kursi DPR atau memperoleh $25 \%$ (dua puluh lima persen) dari suara sah secara nasional pada Pemilu anggota DPR sebelumnya, yaitu hasil pileg 2014. Dari sisi pelaksanaan pilpres 2004, 2009 dan 2014 dilaksanakan setelah pemilihan umu anggota DPR, DPRD dan DPD, sedangkan untuk pilpres 2019 dilaksanakan serentak dengan pemilu legislatif. Dengan demikian pemilu 2019 pemilu serentak pertama di Indonesia yaitu memilih anggota Dewan Perwakilan Rakyat, anggota Dewan perwakilan Daerah, Presiden dan Wakil presiden, dan untuk memilih anggota Dewan Perwakilan Rakyat Daerah.

\section{DAFTAR PUSTAKA}

Amalia, L. S. (2016). Evaluasi pemilihan presiden langsung. Yogyakarta: Pustaka Pelajar bekerja sama dengan dengan Pusat Penelitian politik LIPI.

Asshiddiqie, J. (1994). Gagasan kedaulatan rakyat dalam konstitusi dan pelaksanaannya di Indonesia: pergeseran keseimbangan antara individualisme dan kolektivismme dalam kebijakan demokrasi politik dan demokrasi ekonomi selama tiga masa demokrasi, 1945-1980an. Jakarta: Ichtiar Baru Van Hoeve.

Asshiddiqie, J. (2009). Komentar atas UndangUndang Dasar Negara Republik Indonesia Tahun 1945. Jakarta: Sinar Grafika.

Budiatri, A. P. (2016). Peta kandidat presiden dalam pemilihan presiden langsung dalam evaluasi pemilihan presiden langsung. In valuasi pemilihan presiden langsung. 
Yogyakarta: Pustaka Pelajar bekerja sama dengan dengan Pusat Penelitian politik LIPI.

Falaakh, M. F. (2006). Konstitusi dalam berbagai lapisan makna. JURNAL KONSTITUSI, 3(3).

Haris, S. (2016). Format pemilihan umum presiden. In Evaluasi Pemilihan Presiden Langsung. Yogyakarta: Pustaka Pelajar bekerja sama dengan dengan Pusat Penelitian politik LIPI.

Hidayanto, M. (2017). Menakar derajat efektivitas pemilu serentak terhadap penguatan sistem presidensil. In Seminar Nasional XXVIII AIPI "Pemilu Serentak Tahun 2019." Yogyakarta: Universitas Gajah Mada dan AIPI.

Komisi Pemilihan Umum. (2004). Pemilu Presiden 2004, Jakarta.

Marijan, K. (2010). Sistem politik Indonesia: konsolidasi demokrasi pasca-Orde Baru. Jakarta: Kencana Prenada Media Group.

Rauta, U. (2014). Menggagas pemilihan presiden yang demokratis dan aspiratif. Jurnal Konstitusi, 11(3), 600-616.

Rositawati, R. (2009). Pemilihan umum presiden dan wakil presiden Indonesia dalam kerangka sistem pemerintahan presidensiil. Jurnal Konstitusi, 11(1).

Soehino. (1998). Ilmu negara. Yogyakarta: Liberty.

Sørensen, G. (2008). Democracy and democratization: processes and prospects in a changing world. Choice Reviews Online (Vol. 31). Colorado: Westview Press Published. https://doi.org/10.5860/choice.31-2931 